\title{
REVIEW
}

Check for updates

Cite this: J. Mater. Chem. B, 2017, 5, 3617
Received 2nd January 2017 Accepted 20th April 2017

DOI: $10.1039 / c 7 t b 00010 c$

rsc.li/materials-b

\section{Periodontal tissue engineering: current strategies and the role of platelet rich hemoderivatives}

\begin{abstract}
Pedro S. Babo, (D) ${ }^{\text {ab }}$ Rui L. Reis (DD ${ }^{\text {ab }}$ and Manuela E. Gomes (DD *ab
The periodontium is the assembly of tissues that anchor the teeth to the bone and acts like a dumper for the forces originated during the mastication. The integrity and function of periodontal tissue can be compromised by periodontitis. This highly prevalent inflammatory disease is clinically treatable, nevertheless the healing outcomes are not consistent with a functional periodontal tissue. Given the complexity of the tissues involved and the healing process of the periodontal wound, the development of therapies leading to consistent and predictable regeneration of functional periodontal tissues, turns out to be a challenge. Tissue engineering may offer the adequate prospects to address such challenge, which are summarized in this manuscript. Periodontal tissue engineering procures to regenerate the periodontal wound by stimulating the self-healing ability of periodontium. Thus, it should include the right combination of adequate cell types, biochemical stimuli and the provision of a stable matrix to drive the regrowth of both soft and hard periodontal tissue while avoiding the collapse of soft gingival tissue into periodontal wound. The use of hierarchically designed compartmentalized systems has been proposed as a viable strategy for the regeneration of the complex structure of periodontium. Platelet rich hemoderivatives (PRHds) have been explored for periodontal tissue engineering as sources of cytokines and structural proteins involved in the modulation of the wound healing. Here will be described the benefits, limitations and solutions for the application of the PRHds in peridontal tissue engineering.
\end{abstract}

\footnotetext{
${ }^{a} 3 B$ 's Research Group - Biomaterials, Biodegradables and Biomimetics, University of Minho, Headquarters of the European Institute of Excellence on Tissue Engineering and Regenerative Medicine, AvePark, 4805-017 Barco GMR, Portugal.E-mail: megomes@dep.uminho.pt

${ }^{b}$ ICVS/3B's - PT Government Associate Laboratory, Braga/Guimarães, Portugal
}

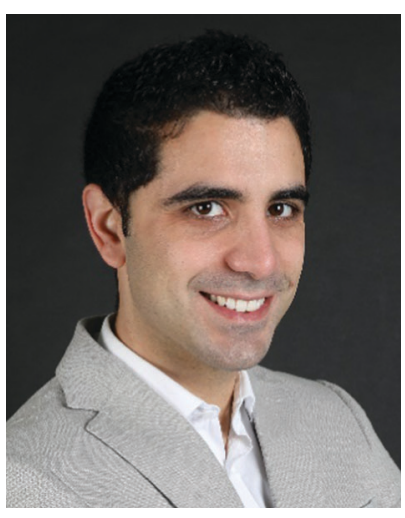

Pedro S. Babo
Dr Pedro S. Babo was graduated in Microbial and Genetics Biology by the Faculty of Sciences of University of Lisbon (FCUL) in 2008. In 2009 he completed his masters in Molecular and Genetics Biology at FCUL. After working in studies on the genetics of rice response to abiotic and biotic stress (ITQB, Oeiras, Portugal), Pedro developed his PhD in the Tissue Engineering and Regenerative Medicine area in $3 B$ 's research group at University of Minho, with a thesis entitled "Platelet Lysate-based tissue engineering approaches for periodontal tissue regeneration". Currently Pedro S. Babo is developing his research as post-doc at $3 B$ 's research group on the application of platelet lysate for endogenous regenerative therapies.

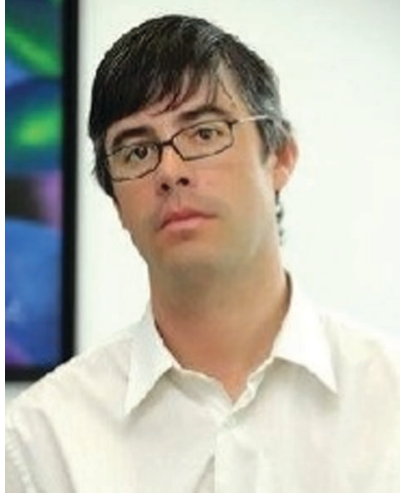

Rui L. Reis
Prof. Rui L. Reis is the Director of the 3B's Research Group, as well as the Director of the PT Government Associate Laboratory ICVS/3B's, and Full Professor at the Department of Polymer Engineering of UMinho. He is the CEO of the European Institute of Excellence on Tissue Engineering and Regenerative Medicine (TERM). He has produced 856 publications listed in ISI WoK, including around 772 articles published in scientific journals with referee, being 69 of those review papers or editorials. He has published 205 book chapters, 25 patents, and more than 1560 communications in conferences, including around 190 invited and plenary lectures in international meetings. He has an ISI h-factor of 75 (87 according to Google Scholar) and over 23375 citations. 


\section{Periodontal tissue and periodontal disease}

The periodontal tissue or periodontium is, as the Greek etymology suggests, the tissue that lies around (peri-) the tooth (-odons). It is a complex structure that anchors the tooth to the maxillary or mandibular bone, while withstanding the forces generated by the masticatory process. The periodontium function is assured by the assembly of specialized tissues with specific morphology and functions, that include the cementum underlying the tooth root surface (Fig. 1D), the periodontal ligament (Fig. 1E), the alveolar bone (Fig. 1C) and a portion of the gingiva facing the tooth (dento-gingival junction (Fig. $\left.1^{*}\right)$ ). ${ }^{1}$

The breakdown of periodontal tissue can occur as a consequence of trauma or periodontitis, compromising its function. Periodontal diseases are highly prevalent, affecting up to $90 \%$ of human population. ${ }^{2}$ The accumulation of microbial plaque in the gingival crevice originates an imbalance in host/ commensal microorganisms' homeostasis, named dysbiosis, inducing an inflammatory response in the gingiva (Fig. 2). This mild-inflammation in gingiva, the gingivitis, does not compromise the underlying tissue. Nevertheless, the chronic gingivitis may induce an immune-inflammatory response in the host, characterized by the formation of a periodontal pocket with resorption of alveolar bone by the action of osteoclasts and general destruction of periodontal supporting tissue termed periodontitis (Fig. 2). ${ }^{3}$ Periodontitis has a multifactorial etiology involving microbial, behavioral (inadequate oral hygiene, alcohol and tobacco use), systemic (immune or metabolic diseases), and genetic factors. ${ }^{4}$

Loss of connective tissue and bone support as result of periodontitis is the major cause of tooth loss in adults. ${ }^{3}$ Besides the aesthetic and functional compromise as result of teeth loss, chronic periodontitis has also a risk of systemic complications, associated with diseases resulting from atherosclerosis, lung diseases, and adverse pregnancy outcomes. ${ }^{3,5}$ In US periodontitis

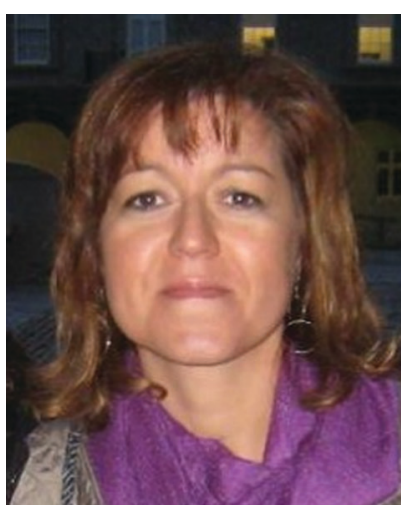

Manuela E. Gomes
Dr Manuela E. Gomes holds a PhD (2005) in Tissue Engineering/ Hybrid Materials (University of Minho, Portugal) in collaboration with the Rice University (USA). She is currently Coordinator Investigator at the 3B's Research Group of the University of Minho and also one of the Vice-Directors of the Group. Manuela Gomes research interests focus on the development of tissue engineering strategies for bone, cartilage and tendon regeneration. M. E. Gomes is author of 32 book chapters, 145 full papers in international refereed journals, and more than 245 communications. She has an $h$ index of 34 (42 according to Google Scholar) and over 4500 citations.

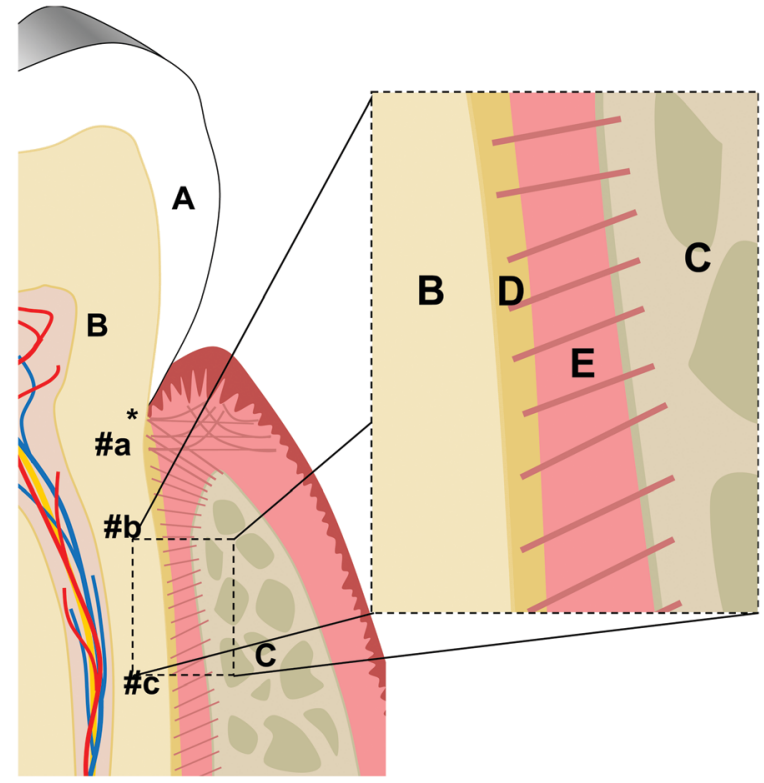

Fig. 1 Normal tooth and periodontal tissue morphology. (A) The crown of tooth or enamel; (B) dentin; periodontal tissue: (C) alveolar bone, (D) cementum, (E) periodontal ligament (periodontal fibers: \#a alveolar crest, \#b horizontal, \#c obliqual fibers), * cementoenamel junction.

is considered a public health issue, affecting $46 \%$ of US adults representing 64.7 million people, with $8.9 \%$ suffering from severe forms of the disease. ${ }^{6}$

\section{Conventional periodontal treatment}

The traditional clinical treatments are based on the halting of disease progression by means of wound site debridement, associated with establishment of excellent oral hygiene. ${ }^{7}$ Nevertheless, the resulting healing patterns are usually not concomitant with the fully functional regeneration of the periodontium (Table 1). ${ }^{7,8}$ The space left void by the destroyed periodontal tissues is usually populated by epithelial cells that migrate 10 times faster than the normal periodontal cell types. Generally, in a periodontal wound, the fast growing of epithelial and gingival tissues usually repopulate the empty space of the periodontal wound. This invasion blocks the repopulation of wound by the cementoblasts, PDL cells, and osteoblasts that could regenerate normal periodontium. Instead, long junctional epithelium is formed. Although the formation of a new epithelial attachment may be compatible with an acceptable clinical outcome and clinical health, it does not regenerate the primitive PDL function. ${ }^{9}$

The use of occlusive membranes was introduced into clinical dental practice in the mid-1980's in order to avoid the population of periodontal wound with gingival cells. This therapy, named guided tissue regeneration (GTR) aimed at promoting the intrinsic healing potential of the alveolar ${ }^{10}$ and periodontal ligament origin cells, ${ }^{11,12}$ that was recently discovered at that time. It was hypothesized them that if cells derived from the PDL and alveolar bone were the first to repopulate tooth root 

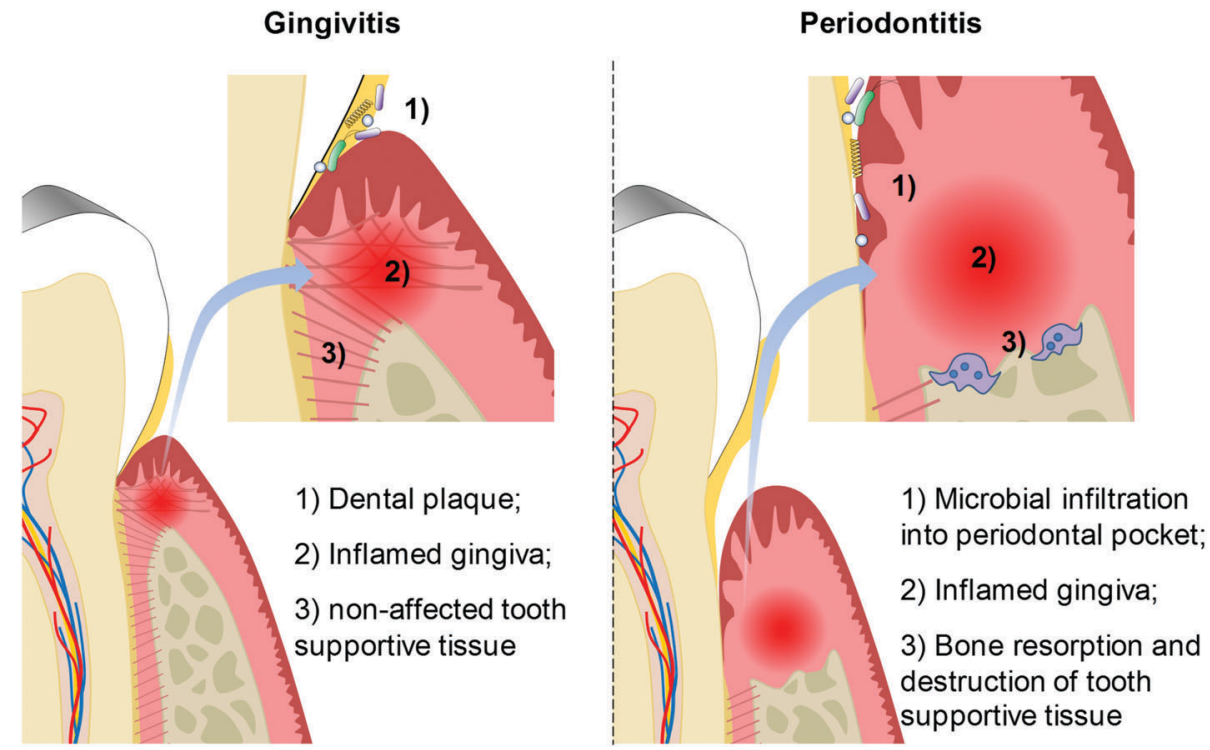

Fig. 2 Periodontal diseases: gingivitis versus periodontitis.

Table 1 Different patterns of periodontal healing/regeneration (based on Chen et al., 2010, ${ }^{7}$ and Polimeni et al., 2006; ${ }^{8}$ adapted from Babo, et al. ${ }^{9}$ )

\begin{tabular}{ll}
\hline Pattern & Characterization \\
\hline $\begin{array}{l}\text { Long junctional epithelium } \\
\text { (epithelial attachment) }\end{array}$ & $\begin{array}{l}\text { Thin epithelial attachment extended apically along the instrumented root surface, which is formed by } \\
\text { keratinocytes that migrate into the pocket from the crevicular epithelium }\end{array}$ \\
Connective tissue repair & $\begin{array}{l}\text { Healing of periodontal defect by collagen fibers oriented parallel or perpendicularly to a instrumented root } \\
\text { surface previously exposed to periodontal disease or otherwise deprived of its periodontal attachment }\end{array}$
\end{tabular}

Bone and/or bone-like tissue repair (ankylosis)

Periodontal tissue regeneration
Healing of periodontal defect by bone or bone-like tissue formation without specific PDL and/or acellular extrinsic fiber cementum regeneration

Healing of the periodontal defect by regeneration of tooth cementum, a functionally oriented PDL, alveolar bone, and gingiva in periodontal defect surface, instead of the fast growing gingival epithelial and connective cells, the formation of a long junctional epithelium would be avoided, and the regeneration of a functional periodontium could be possible. ${ }^{13}$

Nevertheless, the solely creation of an occlusive barrier is unlike to promote full periodontal regeneration, i.e. the restauration of form and function of lost periodontal tissue. This fact justifies an increasing interest in studying tissue engineering approaches that can trigger periodontal regeneration.

\section{Periodontal tissue engineering}

Tissue engineering (TE) emerged as a science that combines the application of principles of engineering and life sciences on behalf of the development of techniques that aim at promoting the regeneration of damaged tissues. ${ }^{7}$ TE approaches aiming at periodontal tissue regeneration have been focusing on the enhancement of the endogenous regenerative potential of the preserved periodontal tissue ${ }^{10-12}$ using materials with a welldefined architecture and providing adequate biochemical stimulus. Pre-requisites for the development of reliable periodontal regenerative therapies are (1) to provide adequate biological cues stimulating the first intentional repair from the preserved tissue; (2) to provide form stability for new tissue ingrowth avoiding the collapse of soft gingival tissue; and (3) to occlude the area from the fast-proliferating gingival fibroblasts., 8

\section{Compartmentalized approaches}

As above described, the periodontal tissue has a complex structure, comprising both soft and hard tissues. Based on the assumption that the regeneration of functional tissues depends on the combination of adequate cells with a scaffold presenting well-defined architectures and biochemical signals, recent TE approaches have proposed compartmentalized systems for the functional and predictable regeneration of periodontium (Fig. 3). ${ }^{15-17}$ Such systems focus on meeting the different characteristics and requirements of the various tissues involved in periodontal defects, mainly targeting the alveolar bone and the periodontal ligament tissues.

Requicha and co-workers ${ }^{18,19}$ created bi-layered membranes based on a blend of starch and polycaprolactone (SPCL) composed by a flat SPCL layer and a SPCL fiber-mesh functionalized with Si groups. The influence of topography and the presence of Si groups stimulated the osteogenic differentiation 

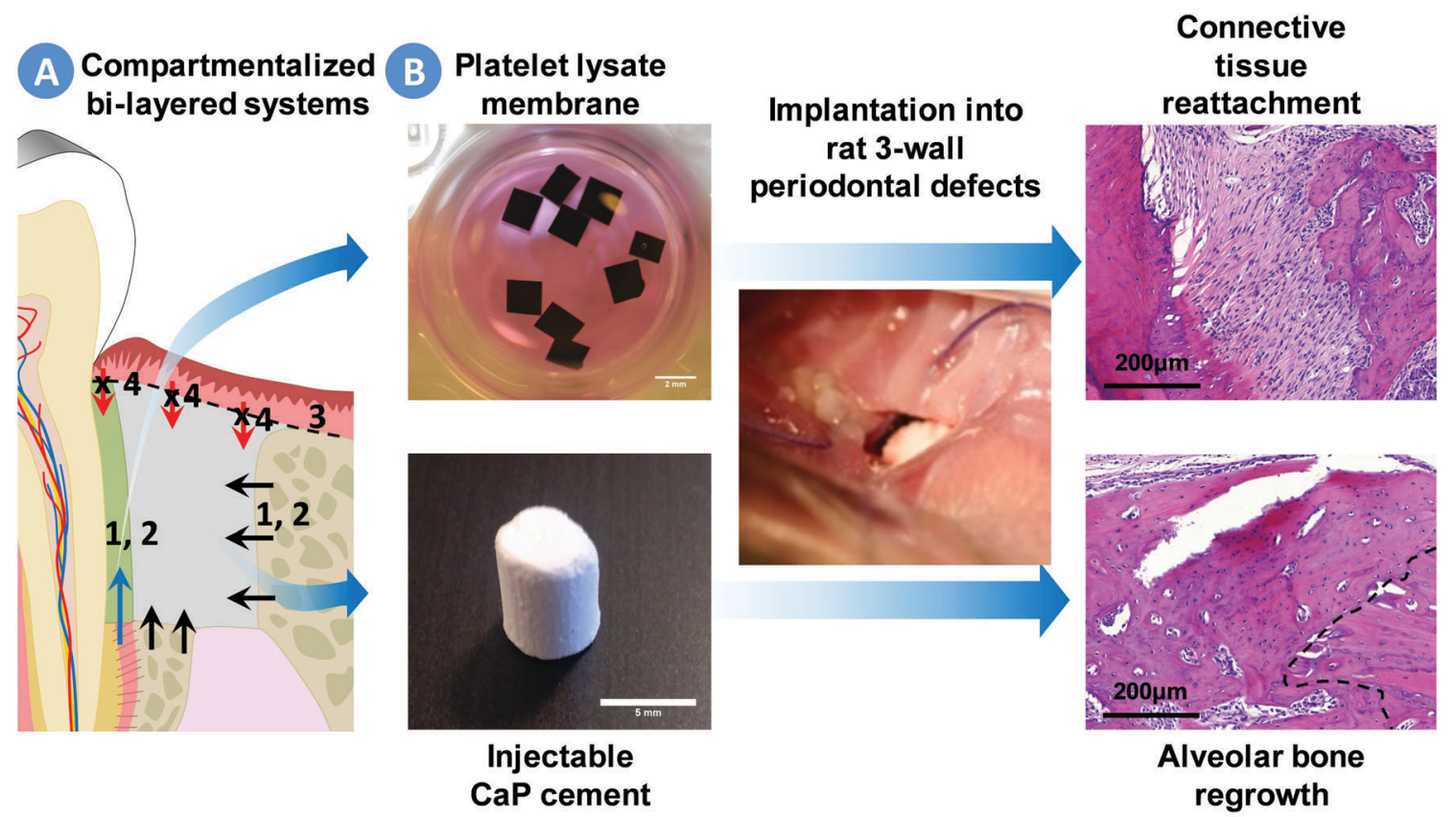

Periodontal tissue engineering principles addressed by compartmentalized systems:

1- Provide adequate biological cues stimulating the first intentional repair from the preserved tissues;

2- Provide adequate substrates for the regeneration of the different tissues involved;

3- Provide form stability for new tissue ingrowth avoiding the collapse of soft gingival tissue;

4- Occlude the area from the fast-proliferating gingival fibroblasts.

Fig. 3 Principles of compartmentalized bi-layered systems. (A) Schematic of a compartmentalized system for periodontal tissue engineering and main principles addressed by these systems; (B) compartmentalized bi-layered system proposed by Babo et al. 2016,17 composed by a platelet lysate membrane aiming PDL regeneration and an injectable calcium phosphate (CaP) cement for alveolar bone regeneration tested in a periodontal defect in rats. Representative histologic micrographs showing the connective tissue reattachment and alveolar bone regrowth.

of canine adipose derived stem cells (cASCs) in vitro. ${ }^{18}$ The double-layered membrane was also assessed in a mandibular rat defect model and compared to a commercial collagen membrane (Parasorb Resodont, Resorba, Germany). ${ }^{19}$ The SPCL-Si scaffolds induced significantly higher new bone formation in 8 weeks showing better results than the positive control. ${ }^{19}$ Iwata and co-workers $^{20}$ proposed a multi-layered system in which canine PDLCs cell sheets, supported by a woven polyglycolic acid matrix, were transplanted to dental root surfaces and porous $\beta$-tricalcium phosphate ( $\beta$-TCP) was used to fill the bone defect area. They were able to regenerate both new bone and cementum connecting with well-oriented collagen fibers in a canine 3 -wall periodontal defect. ${ }^{20}$ Costa, et $a .^{21}$ tested a bi-layered system composed by cell sheets of periodontal ligament cells (PDLCs) targeting the regeneration of PDL combined with a PCL mesh coated with $\beta$-TCP for the regeneration of alveolar bone. The in vivo ectopic implantation of this compartmentalized bi-layered system was able to promote the regeneration PDL-like tissue in the PDLCs cell sheet compartment and the deposition of new bone in the PCL mesh. ${ }^{21}$

The combination of state-of-art imaging and tri-dimensional printing technologies has allowed the printing of tailor-made compartmentalized constructs emulating the specific shape of the target periodontal defect. ${ }^{22-24}$ The three-dimensional bioprinting allows for reproduction of specific features mimicking the microarchitecture of the PDL and alveolar bone, or the situspecific delivery of cells and biochemical cues.

\section{Delivery of adequate cell types}

The cells isolated from the periodontal ligament (PDLCs) have been widely explored for periodontal TE. Among the PDLCs, are found stem cells (PDLSCs) that express the mesenchymal stem-cell markers STRO-1 and CD146/MUC18, ${ }^{25}$ that are able to differentiate into several cell lineages, namely chondrogenic, ${ }^{26}$ osteogenic, ${ }^{27}$ cementoblastogenic, adipogenic, and collagen-forming cells. $^{25}$ Moreover, PDLSCs have the capacity to generate a cementum/ PDL-like structure ectopically, ${ }^{25}$ as well as to contribute for periodontal tissue repair in animal models..$^{20,25,28}$ However, given the limited amount on PDL stem cells available in a patient suffering of periodontal tissues loss, other oral and non-oral sources have been also been considered, namely bone marrow mesenchymal stem cells (MSCs), ${ }^{29}$ embryonic stem cells (ESCs), ${ }^{30}$ adipose tissue derived stem cells (ASCs) ${ }^{18,31,32}$ gingival fibroblasts ${ }^{33}$ or genetically engineered cells ${ }^{34}$ (revised in detail in ref. 35).

\section{Growth factors}

In addition to an adequate matrix, the TE approaches should be able to orchestrate temporally and spatially the complex sequence of events that are involved in the natural formation 
and development of periodontium. ${ }^{8}$ The growth factors (GFs) that have been found more relevant for periodontal regeneration are PDGF, IGFs, FGF, TGF- $\beta$, and BMPs. ${ }^{7}$ The use of growth factors with osteogenic potential, namely transforming growth factor-beta (TGF- $\beta$ ) and bone morphogenic proteins (BMPs) have been tested for the regeneration of alveolar bone, while no significant effect in new connective tissue attachment was achieved. ${ }^{36}$ Fibroblast growth factor (FGF) which is mitogenic for PDLFs and induces osteogenic phenotype in vitro, ${ }^{37}$ was shown to enhance both alveolar bone and PDL regeneration in a rat 3-wall defect. ${ }^{36}$ The combination of different growth factors is expected to have a synergistic effect on the regulation of periodontal regeneration.

\section{Platelet-rich hemoderivatives}

Polimeni et al., ${ }^{8}$ revising the periodontal healing and regeneration mechanisms, refers the importance of the stabilization of blood clot on root surface to avoid epithelial downgrowth, and promote periodontal tissue regrowth. Platelet-rich hemoderivatives (PRHds) have been explored for TE applications as a simple and cost effective source of GFs, cytokines and structural proteins with key roles in the regeneration of bone and soft tissues. ${ }^{38-40}$ The Table 2 summarizes the principal GFs found in PRHds with interest for periodontal TE. Among the growth factors abundant in the PRHds are the transforming growth factor- $\beta$ (TGF- $\beta$ ), insulin growth factor-1 (IGF-1), endothelial growth factor (EGF), platelet derived growth factor (PDGF), vascular endothelial growth factor (VEGF) and fibroblast growth factor (FGF). ${ }^{41-43}$ These soluble factors are involved in essential stages of wound healing and regenerative processes such as chemotaxis, cell proliferation and differentiation. ${ }^{43-45}$ Moreover, the PRHds are rich in structural proteins, such as fibrinogen ${ }^{46}$ (or its polymerized product fibrin), and fibronectin, ${ }^{47}$ which may act as a provisional matrix for cell adhesion and migration. ${ }^{40}$ Some PRHds have also been reported to exhibit antimicrobial properties, ${ }^{48-50}$ attributed to the presence of $\beta$-lysin, ${ }^{51}$ neutrophil activating protein- $2,{ }^{52,53}$ or platelet factor- $4,{ }^{54,55}$ which can contribute for maintaining the prophylaxis of the wound site. For TE, the PRHds can be used directly or in combination of adequate biomaterials (Table 3), depending on the treatment goal and targeted tissue: delivery of growth factors; cell transplantation; enhance tissue-integration of grafts; improve the mechanical properties of the system.

The PRHds include several different products, which can be roughly classified into platelet rich plasma (PRP), platelet rich fibrin (PRF) or platelet lysate (PL). They can be obtained by several methods, usually after the centrifugation of whole blood, in order to produce a platelet concentration over the physiologic

Table 2 Growth factors isolated from platelet rich hemoderivatives and its potential role for the regeneration of periodontal tissue

\begin{tabular}{|c|c|c|c|c|}
\hline $\begin{array}{l}\text { Growth } \\
\text { factor }\end{array}$ & Recommended name & Physiologic functions & $\begin{array}{l}\text { Potential role in } \\
\text { periodontal regeneration }\end{array}$ & Ref. \\
\hline BMP-2 & Bone morphogenetic protein 2 & Induces cartilage and bone formation & Alveolar bone regeneration & 114 \\
\hline BMP-4 & Bone morphogenetic protein 4 & Induces cartilage and bone formation & Alveolar bone regeneration & 114 \\
\hline BMP-6 & Bone morphogenetic protein 6 & Induces cartilage and bone formation & Alveolar bone regeneration & 114 \\
\hline PDGF AA & $\begin{array}{l}\text { Platelet-derived growth } \\
\text { factor AA }\end{array}$ & $\begin{array}{l}\text { Plays an important role in wound } \\
\text { healing. Promotes cellular proliferation, } \\
\text { migration, survival and chemotaxis }\end{array}$ & $\begin{array}{l}\text { Recruitment of progenitor cells } \\
\text { from preserved periodontal } \\
\text { tissue; cell proliferation }\end{array}$ & $\begin{array}{l}104 \text { and } \\
114-117\end{array}$ \\
\hline PDGF AB & $\begin{array}{l}\text { Platelet-derived growth } \\
\text { factor } \mathrm{AB}\end{array}$ & $\begin{array}{l}\text { Plays an important role in wound } \\
\text { healing. Promotes cellular proliferation, } \\
\text { migration, survival and chemotaxis }\end{array}$ & $\begin{array}{l}\text { Recruitment of progenitor cells } \\
\text { from preserved periodontal } \\
\text { tissue; cell proliferation }\end{array}$ & 76,103 and 114 \\
\hline PDGF BB & $\begin{array}{l}\text { Platelet-derived growth } \\
\text { factor BB }\end{array}$ & $\begin{array}{l}\text { Plays an important role in wound } \\
\text { healing. Promotes cellular proliferation, } \\
\text { migration, survival and chemotaxis }\end{array}$ & $\begin{array}{l}\text { Recruitment of progenitor cells } \\
\text { from preserved periodontal } \\
\text { tissue; cell proliferation }\end{array}$ & $\begin{array}{l}41,46,103,115 \\
\text { and } 118\end{array}$ \\
\hline TGF- $\beta 1$ & $\begin{array}{l}\text { Transforming growth } \\
\text { factor beta-1 }\end{array}$ & $\begin{array}{l}\text { Plays an important role in bone } \\
\text { remodeling; stimulator of osteoblastic } \\
\text { bone formation, causing chemotaxis, } \\
\text { proliferation and differentiation in } \\
\text { osteoblast precursor cells }\end{array}$ & $\begin{array}{l}\text { Recruitment and differentiation } \\
\text { of pre-osteoblasts for the } \\
\text { regeneration of alveolar bone }\end{array}$ & $\begin{array}{l}41,42,46,76 \\
103,115 \text { and } \\
117\end{array}$ \\
\hline TGF- $\beta 2$ & $\begin{array}{l}\text { Transforming growth } \\
\text { factor beta- } 2\end{array}$ & $\begin{array}{l}\text { Stimulates the proliferation of osteoblast } \\
\text { precursor cells, and bone collagen } \\
\text { synthesis. TGF- } \beta 2 \text { has suppressive effects } \\
\text { on interleukin- } 2 \text { dependent T-cell growth }\end{array}$ & $\begin{array}{l}\text { Recruitment of and differentia- } \\
\text { tion of pre-osteoblasts for the } \\
\text { regeneration of alveolar bone }\end{array}$ & $\begin{array}{l}103,115 \text { and } \\
116\end{array}$ \\
\hline IGF-I & Insulin-like growth factor I & $\begin{array}{l}\text { Stimulates glucose transport in osteo- } \\
\text { blasts and is effective at much lower } \\
\text { concentrations than insulin }\end{array}$ & Alveolar bone regeneration & $\begin{array}{l}41,76,103,104, \\
115 \text { and } 116\end{array}$ \\
\hline VEGF & $\begin{array}{l}\text { Vascular endothelial } \\
\text { growth factor }\end{array}$ & $\begin{array}{l}\text { Induces endothelial cell proliferation, } \\
\text { promotes cell migration, inhibits } \\
\text { apoptosis and induces permeabilization } \\
\text { of blood vessels }\end{array}$ & $\begin{array}{l}\text { Recruitment of progenitor cells } \\
\text { to the periodontal wound; } \\
\text { revascularization }\end{array}$ & $\begin{array}{l}41,42,46,76 \\
\text { and } 116\end{array}$ \\
\hline TSP-1 & Thrombospondin-1 & $\begin{array}{l}\text { Major activator of TGF- } \beta 1 \text {, may play } \\
\text { a role in dentinogenesis and/or } \\
\text { maintenance of dentin and dental pulp }\end{array}$ & Cementum regeneration & 76, 116 and 119 \\
\hline bFGF & Basic-fibroblast growth factor & $\begin{array}{l}\text { Plays an essential role in the regulation } \\
\text { of cell proliferation, differentiation, } \\
\text { migration and apoptosis, and in the } \\
\text { regulation of embryonic development }\end{array}$ & $\begin{array}{l}\text { Promotes the proliferation and } \\
\text { migration of periodontal } \\
\text { ligament fibroblasts }\end{array}$ & 41, 42 and 104 \\
\hline
\end{tabular}


Table 3 Platelet-rich hemoderivatives-based tissue engineering strategies. Abbreviations: PRHds (platelet-rich hemoderivatives); PRP (platelet-rich plasma); PG (platelet gel); PRGF (plasma rich in growth factors); PL (platelet lysate); GFs (growth factors); HA (hyaluronic acid); HAp (hydroxyapatite); DFDBA (demineralized freeze-dried bone allograft); $\beta$-TCP ( $\beta$-tricalcium phosphate); FDBA (freeze-dried bone allograft); BCP (biphasic calcium phosphate), Ti (titanium implants)

\begin{tabular}{|c|c|c|c|c|}
\hline $\begin{array}{l}\text { Tissue engineering } \\
\text { approaches }\end{array}$ & Biomaterials & PRHds & Aims & Ref. \\
\hline $\begin{array}{l}\text { Fibrin hydrogels/ } \\
\text { membranes }\end{array}$ & PRHds & $\mathrm{PRF}, \mathrm{PG},{ }^{a} \mathrm{PL}^{a}$ & $\begin{array}{l}\text { - GFs delivery; } \\
\text { - Provisional matrix for progenitor cells delivery }\end{array}$ & $\begin{array}{l}66,75,85,86 \\
89,90 \text { and } 120\end{array}$ \\
\hline Encapsulation into hydrogels & $\begin{array}{l}\text { HA, silk, alginate, } \\
\text { gelatin }\end{array}$ & PRP, PRGF, PL & $\begin{array}{l}\text { - Release of GFs in a sustained manner; } \\
\text { - Extend the time of GFs release; } \\
\text { - Enhance encapsulated cells viability }\end{array}$ & $50,68,81$ and 82 \\
\hline Mixing with ceramics & НАр, $\beta$-ТСР, ВСР & PRP, PRF, PL & $\begin{array}{l}\text { - Modulate the osteogenic potential of } \\
\text { the PRHds; } \\
\text { - Improve the aggregation and cohesiveness } \\
\text { of particulate ceramics }\end{array}$ & $79,87,121$ and 122 \\
\hline $\begin{array}{l}\text { Mixing with particulate } \\
\text { vital/demineralized/ } \\
\text { decellularized bone }\end{array}$ & $\begin{array}{l}\text { Particulate cancellous } \\
\text { bone, DFDBA, FDBA }\end{array}$ & PRF, PRP, PG & $\begin{array}{l}\text { - Improve the aggregation and cohesiveness } \\
\text { of particulate bone; } \\
\text { - Enhance the viability of live tissue; } \\
\text { - Promote bone regeneration }\end{array}$ & 70,78 and 88 \\
\hline Surface coating & $\mathrm{Ti}$ & PRP, PRGF, PL & $\begin{array}{l}\text { - Enrich grafts' surface with fibrin and } \\
\text { growth factors; } \\
\text { - Enhance tissue integration }\end{array}$ & 65 and 83 \\
\hline $\begin{array}{l}\text { Membranes/sponges } \\
\text { of chemically } \\
\text { crosslinked PRHds }\end{array}$ & PL (+genipin) & PL & $\begin{array}{l}\text { - Thrombin-free scaffolds; } \\
\text { - Delivery of GFs; } \\
\text { - Cell carriers }\end{array}$ & 95 \\
\hline
\end{tabular}

levels (Fig. 4). This product can be allowed to clot spontaneously, together with the remaining blood components, in order to produce a platelet rich fibrin (PRF) clot (Fig. 4C); ${ }^{56}$ alternatively, it can be collected and submitted to further centrifugation steps to produce platelet concentrates (PC) (Fig. 4D). ${ }^{57}$ The PC or the
PRP can be used directly or activated using several methods, including the addition of thrombin, ${ }^{58}$ thromboplastin, ${ }^{59}$ calcium salts $^{58-61}$ or collagen ${ }^{62}$ (Fig. 4E). The platelet lysate (PL) can be obtained after processing PRP or PC by freeze/thaw cycles ${ }^{41,42}$ of by ultrasounds ${ }^{63}$ in order to disrupt the platelets' membranes (Fig. $4 \mathrm{~F}$ ).
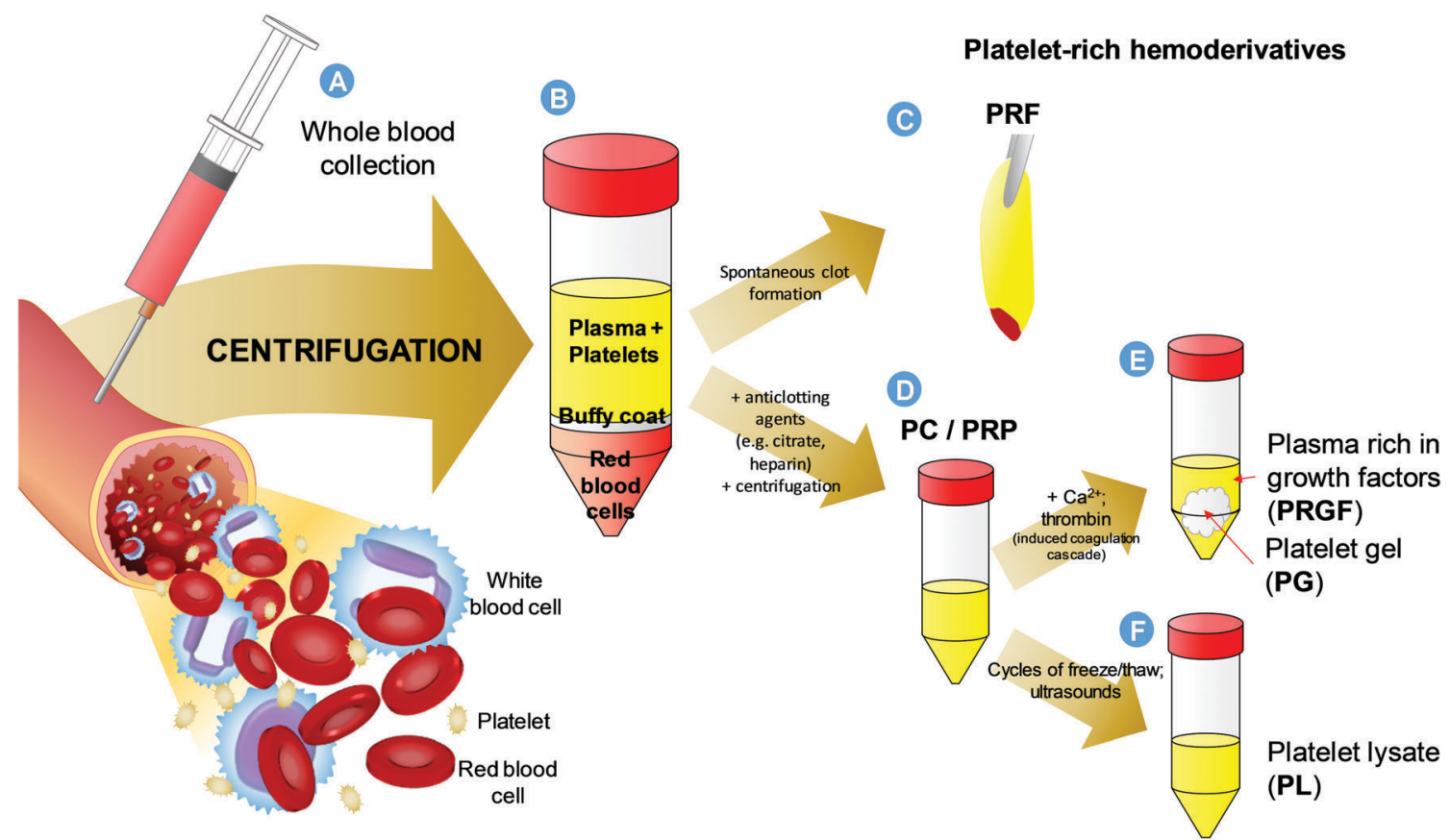

Fig. 4 Platelet-rich hemoderivatives (PRHds). (A) The centrifugation of whole blood (B) induces the separation of the blood components into 3 layers. (C) The upper layer, a yellowish solution composed mainly of plasma and platelets, coagulate spontaneously if no anticlotting agent was previously added to the whole blood, originating a fibrin mesh rich in platelets and leucocytes termed platelet rich plasma (PRF). (D) The platelet concentrate (PC) also called platelet-rich plasma (PRP) can be obtained from the upper layer of centrifuged whole blood supplemented with anticlotting agents or by plasmapheresis. (E) The PC or PRP can suffer clotting induction, originating the platelet gel (PG), and plasma rich in growth factors (PRGF). (F) Alternatively, the platelets of PC or PRP can be disrupted by freeze/thaw cycles or by ultrasounds, originating a solution of platelet lysate (PL). 
Other PRHDs subtypes can be defined based on the leukocyte content (more information can be found elsewhere). ${ }^{64}$

\section{Platelet-rich plasma (PRP)}

PRP was defined by Marx ${ }^{57}$ as a volume of autologous plasma that has a platelet concentration above blood baseline (between $1.5 \times 10^{5} \mu \mathrm{l}^{-1}$ and $3.5 \times 10^{5} \mu \mathrm{l}^{-1}$ ). Since the concentration of platelets that has been proven to have therapeutic efficacy for bone healing is around $1 \times 10^{6} \mu \mathrm{l}^{-1,57,65}$ this has been established as the platelet content that defines a platelet suspension as PRP. ${ }^{57}$ Any platelet suspension in plasma with a concentration above baseline can be termed platelet concentrate (PC). However, in literature, some works using "PRP" either overlock the platelet concentration ${ }^{66}$ or use PC at different other. ${ }^{67}$ PRP can be used directly or activated with thrombin and/or $\mathrm{Ca}^{2+}$ promoting the formation of a fibrin network containing activated platelets, termed platelet gel (PG), as depicted in Fig. $4 \mathrm{E} .^{68}$ The supernatant, a solution of GFs, released upon platelets activation, in blood plasma is called plasma rich in growth factors (PRGF) ${ }^{43,49}$ PRP has been proposed for TE applications as a source of autologous growth factors (GFs). ${ }^{57}$ Moreover, its fibrin meshes are adequate vehicles for mesenchymal stem cells (MSCs) transplantation. ${ }^{69}$ Therefore, PRP and its derivatives have been studied for the regeneration of several tissues including bone, ${ }^{57,70}$ cartilage $^{71}$ and tendon. ${ }^{72}$ Additionally, PRP was shown to be an alternative to the xenogenic fetal bovine serum as culture media supplementation for the expansion of ASCs, ${ }^{73}$ and MSCs. ${ }^{74}$

Whitman et al.,$^{70}$ in 1997, were the first to promote the use of PRP, as PG, in oral surgical procedures. It was shown to improve the aggregation and cohesiveness of particulate bone, enhancing the osteogenesis in palatal bone defects. ${ }^{70}$

Regarding the repair of periodontal tissue, the application of PRP along with the conventional periodontal therapies has produced comparable or improved outcomes. For instance, PRP administration after open flap debridement (OFD) produced higher clinical attachment level (CAL) than OFD alone in the treatment of mandibular degree II furcation defects in subjects suffering of chronical periodontitis. ${ }^{66}$ Moreover, PRP alone or associated with a collagen GTR membrane enhanced the attachment and reduced the periodontal pocket deep in apicomarginal defects treated in clinic. ${ }^{75}$ PRGF exerts positive effects on periodontal ligament fibroblasts (PDLFs), namely promoting their proliferation and migration, ${ }^{76}$ which could justify the positive effect of PRP on re-gain of teeth attachment after periodontal disease.

It is more or less established that PRP has a positive effect in the treatment of periodontal soft tissues. ${ }^{77}$ Nevertheless, PRP seems to be more effective when combined with other materials. ${ }^{77}$ Actually, PRP might enhance the osteogenic properties of the bone grafts and maintains the cohesiveness of the materials. ${ }^{70}$ The combination of PRP with demineralized freeze-dried bone allograft (DFDBA) produced significantly greater clinical improvement in infrabony periodontal defects than DFDBA with saline. ${ }^{78}$ Similar results were reported for sinus floor augmentation, using PRP along with $\beta$-tricalcium phosphate $\left(\beta\right.$-TCP).$^{79}$ Nevertheless, the effect of PRP on bone augmentation is still inconclusive. ${ }^{77,80}$
Some works have investigated the possibility to modulate the release of PRP growth factors, as the effect of PRP alone seems to disappear a few days after administration. ${ }^{77}$ The incorporation of PRP into hydrogels seems to be an adequate alternative. ${ }^{68,81,82}$ Fernandes and co-workers ${ }^{81}$ showed that the encapsulation of PRP into alginate microbeads promoted the sustained release of PDGF. Moreover, this system promoted faster obliteration of the sagittal and coronal cranial sutures of mice embryonic calvaria. ${ }^{81}$

Finally, the coating of dental metallic implants with PRP proteins improves their tissue integration. For instance, the osteointegration of Ti implants was enhanced by coating the implant surface with PRGF prior to insertion into the alveolus. ${ }^{83}$

\section{Platelet-rich fibrin (PRF)}

PRF consists of an autologous leukocyte-platelet-rich fibrin matrix. ${ }^{84}$ It is a second generation PRHd proposed by Choukroun $^{56}$ as an easier to prepare and completely autologous alternative to PRP (Fig. 4C).

For periodontal TE applications, adjunctive use of PRF with OFD significantly improves the treatment of two and three wall infrabony defects fill when compared to OFD alone 9 months post operatively. ${ }^{85,86}$ The CAL obtained for degree II furcation defects 9 months after the combined treatment of PRF and OFD or PRP and OFD is comparable. ${ }^{66}$ In fact, the results reported for PRF in periodontal treatment are very similar to those reported for PRP. ${ }^{86}$

PRF was also shown to have a positive clinical impact in the treatment of infrabony defects when combined with an alloplast graft composed of $\beta$-tricalcium phosphate ( $\beta$-TCP) and hydroxyapatite (HAp) (OssiFi $\left.{ }^{\mathrm{TM}}\right) .{ }^{87}$ Moreover, the combination of PRF freeze-dried bone allograft (FDBA) reduced the healing time in sinus floor elevation. ${ }^{8}$

The use of PRF membranes as cell-delivery vehicles for periodontal TE was also proposed. Wang and co-workers ${ }^{89}$ proposed a multiphasic system composed of human PDL stem cells (PDLSCs) and jaw bone mesenchymal stem cells (JBMSCs) cell sheets placed on both the sides of a PRF membrane. This system tested in vitro in simulated periodontal space comprising human treated dentin matrix (TDM) and hydroxyapatite (HA)/tricalcium phosphate (TCP) frameworks originated PDL- and bone-like tissue, after eight weeks in culture.

\section{Platelet lysate (PL)}

PL is obtained by disruption of the platelets contained in PC batches, either produced by centrifugation cycles $^{42}$ or by apheresis. ${ }^{41,42,90}$ It is a solution which contains most of the growth factors common to PRHds. ${ }^{41,42}$ Therefore, the human PL (hPL) has been proposed as prevailing alternative to fetal bovine serum (FBS) supplement for several human cell culture ${ }^{41,91}$ Long term culture of human bone marrow stem cells (hMSC) in medium supplemented with hPL maintained the multipotency of hMSC, while protecting against the clonal chromosomal instability detected in the FBS milieu. ${ }^{41}$ Similar results were reported by Trubiani and co-workers ${ }^{92}$ for the expansion of hPDLSCs. 
Table 4 Comparison between the properties of platelet rich hemoderivatives, based on $46,49,51,55$

\begin{tabular}{|c|c|c|c|c|c|c|}
\hline $\begin{array}{l}\text { Platelet rich } \\
\text { hemoderivative }\end{array}$ & $\begin{array}{l}\text { Clot } \\
\text { retraction }\end{array}$ & Standardization & $\begin{array}{l}\text { Batch-to-batch } \\
\text { variability }\end{array}$ & $\begin{array}{l}\text { Introduction of } \\
\text { xenogenic material }\end{array}$ & $\begin{array}{l}\text { Readily } \\
\text { available }\end{array}$ & $\begin{array}{l}\text { Autologous } \\
\text { therapy }\end{array}$ \\
\hline Platelet rich plasma & Yes & No & High & Yes $^{a}$ & $\mathrm{No}^{b}$ & Yes \\
\hline
\end{tabular}

${ }^{a}$ When activated with xenogenic thrombin. ${ }^{b}$ Needs blood collection from patient. ${ }^{c}$ Usually proposed as an allogenic approach.

PL offer several advantages over PRP and PRF for therapeutic applications (Table 4): (1) the clot and platelet debris are removed during PL processing, therefore, the PL is a solution that hardly forms spontaneously a gel or retracts; (2) the freeze/ thaw cycles are easy to standardize and do not require the addiction of any clot activator to release the platelet factors; (4) the concentration of the growth factors and cytokines is highly reproducible between batches, which can contribute for more predictable outcomes; (3) it can be frozen and stored to be readily available for further use. ${ }^{41}$

For TE applications, PL can be processed into a gel using thrombin $^{63}$ or loaded into carries for the sustained release PL-origin factors. ${ }^{50,93,94}$ These constructs incorporating PL shown potential to induce neovascularization, ${ }^{63}$ osteogenesis $^{93,94}$ and enhance periodontal re-attachment. ${ }^{17}$

Santo et $a l .{ }^{93}$ incorporated PL into chondroitin sulfate/ chitosan nanocarriers, which were able to replace FBS supplementation in human adipose derived stem cells (hASCs) cultures without compromising cell proliferation. Moreover, the release of PL from nanocarriers was shown to enhance osteogenic commitment of hASCs. ${ }^{93}$ PL can be also incorporated into photocrosslinkable hydrogels produced by dissolution of a methacrylated glycosaminoglycan (e.g., hyaluronic acid ${ }^{50}$ ) into PL and using an adequate photoinitiator. The produced hydrogels are able to release growth factors with therapeutic interest in a controlled manner, support the adhesion and proliferation of hPDLFs, displaying bacteriostatic properties against Staphylococcus aureus. ${ }^{50}$ In a previous study we described the production of PL-based membranes by selfcrosslinking of PL proteins with the natural origin crosslinker genipin. ${ }^{95}$ This membranes were proved to be stable and nonretractable for up to 28 days in PBS solution, and released basic fibroblast growth factor (bFGF), a potent mitogen for PDLCs, ${ }^{92}$ in a sustained manner. ${ }^{95}$ Furthermore, the PL-based membranes were shown to provide adequate substrates for hASCs adhesion an proliferation, ${ }^{95}$ thus suggesting the potential of PL to be used as raw material for TE therapies. In order to evaluate the potential of the PL-based membranes to regenerate the PDL, a bi-layered system composed of the membrane and an injectable CaP incorporating PL-loaded PLGA microspheres was tested in a rat infrabony 3-wall periodontal defect. ${ }^{17}$ The delivery of PDLCs with the membranes did not produce therapeutic benefits, however, the stabilization of the PL-based construct over the tooth root significantly promoted the re-growth of periodontal tissue. ${ }^{17}$

\section{Challenges for PRHds-based periodontal tissue engineering}

In fact, the application of PRP or PRF has been proved to be a real asset for periodontal TE, with improved ${ }^{86}$ or comparable c6,97 $^{96}$ clinical outcome in terms of gain of periodontal support with conventional periodontal therapies such as open flap debridement $^{66,86}$ or GTR occlusive barriers. ${ }^{96}$ Still, the outcomes of the PRP (and PRF) are fairly variable, ${ }^{97}$ and, despite the promising effectiveness of these hemoderivatives for periodontal regeneration reported by some authors, others reported no beneficial ${ }^{98,99}$ or even an inhibitory effect ${ }^{100}$ for bone augmentation.

The causes of the variability can be related with the severity of the defects, the choice of the grafting materials or patient predisposition to periodontal disease. ${ }^{97}$ However, the heterogeneity of the techniques employed for the preparation of PRHds, namely the different platelet concentrations used, ${ }^{65,101}$ and the activation protocol might also interfere with the predictability of the treatment outcomes. Commercially available kits (e.g. PRGF ${ }^{\mathbb{R}}$-Endoret ${ }^{\circledR}$, PCCS $^{\mathbb{R}}$, Harvest $^{\mathbb{R}}$ SmartPrep ${ }^{\circledR}$ ) have aimed at establishing good manufacturing practice (GMP)-adherent protocols for PRP derivatives production, reducing the protocolrelated variability. Nevertheless, different PRP preparation kits still yield significantly different platelets concentration. ${ }^{67,101}$ In a study, PCCS ${ }^{\circledR}$ PRP preparation yielded $1641800 \pm 426820$ platelets per $\mu \mathrm{l}$, and the PRGF ${ }^{\mathbb{R}}$-Endoret ${ }^{\mathbb{R}}$ kit PRP preparation $513630 \pm 139470$ platelets per $\mu \mathrm{l}$, with a proportional difference in GFs content. ${ }^{67}$ Additionally, since the PRP and PRF have been touted as autologous approaches, the donor-to-donor variability can be an imponderable factor too. ${ }^{43,102,103}$

$\mathrm{PRP}^{104}$ and $\mathrm{PL}^{41}$ pools of different donors yield more consistent cytokine contents and single-donor batches. Moreover, human PL pools produced using good manufacturing practices (GMPs)-adherent protocols showed viral and bacterial sterility. ${ }^{41}$ Regarding the use of PL as an adjuvant for periodontal TE, the studies are still very incipient. Given the above endorsed arguments for the use of PL in therapeutic applications, and its versatility, novel PL-based periodontal TE systems are expected.

Regarding the effect of the PRHds' GFs in tissue regeneration, it is very unlikely that a protein cocktail which is able to maintain the differentiation potential of stem cells isolated from several different tissues, ${ }^{41,42,76,105,106}$ would be able to promote by its own the cell differentiation. In fact, the cytokines present in the PRHds correlate mainly to wound healing processes. ${ }^{41,43}$ Nevertheless, the periodontal healing outcomes (Table 1) are not concomitant with the fully regain of periodontal function, as demanded by periodontal TE. Future strategies should procure to drive the specific GFs to the adequate periodontal compartment. For instance, the bFGF is known to have a pro-angiogenic effect ${ }^{107}$ and to promote the proliferation of PDLCs ${ }^{108}$ (see Table 2 and Fig. 5). Therefore, for TE strategies envisioning the regain of periodontal attachment, its delivery is 


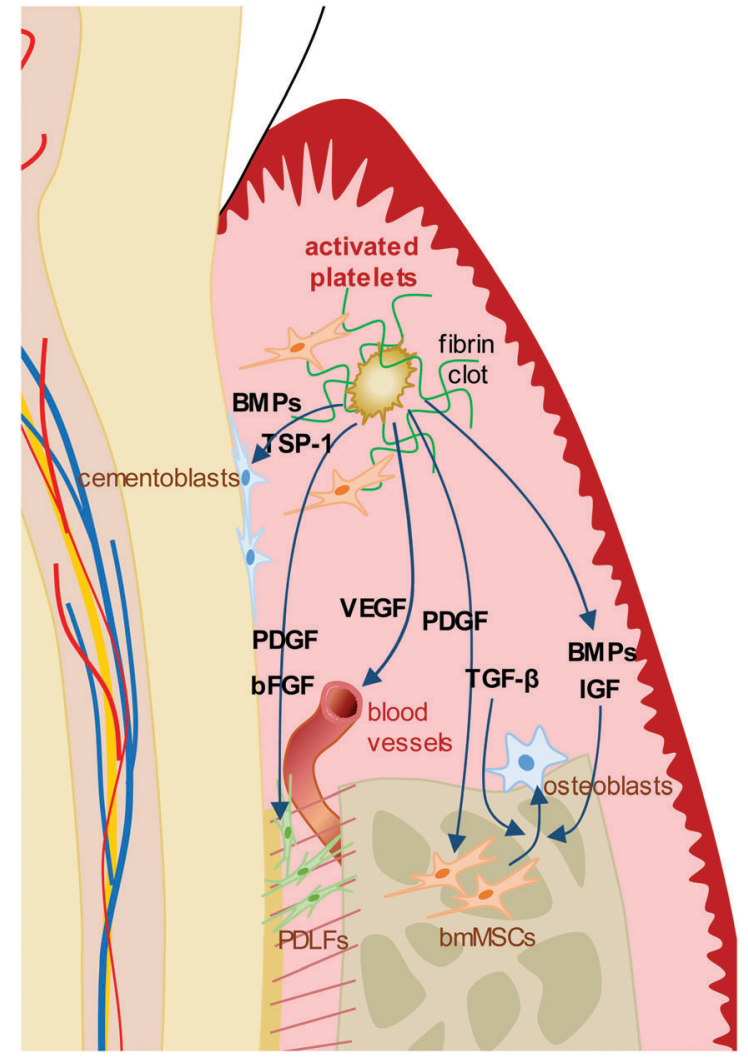

Fig. 5 Role of platelets in periodontal healing. The chemotactic growth factors released from activated platelets (PDGF, TGF- $\beta$, bFGF) recruit progenitor cells from the preserved periodontal tissue, namely periodontal ligament fibroblasts (PDLFs) and mesenchymal stem cells from alveolar bone marrow (bmMSCs). The fibrin clot provides a provisional matrix for cell colonization of the defect area and the mitogenic effect of some growth factors (PDGF, bFGF) promote cell proliferation. The release of angiogenic factors (VEGF) will enhance the formation of new vascular tissue and accelerate the healing process. Finally, the morfogenic factors (TGF- $\beta$, BMPs, IGF, TSP-1) promote the progenitor cells differentiation into new periodontal tissue.

expected to be more effective in the PDL compartment. ${ }^{36}$ However, for hard tissue regeneration, namely alveolar bone and cementum, the morphogenic factors BMPs, TGF- $\beta$, TSP1 and IGF, are needed. These GFs exist among PRHds cytokines, however, the anti-morphogenic PDGFs ${ }^{100}$ too, which could justify the impaired osteogenic potential of PRHds. ${ }^{100,109}$ The use of osteogenic materials together with PRHds has a synergistic effect. Nevertheless, the choice of an adequate material might modulate the cytokines presented to the cells. Most of the GFs have basic pI (TGF- $\beta$ at pH 8.90; PDGF-A at pH 9.52; PDGF-B at pH 9.39; VEGF-1 at pH 8.66; FGF-2 at pH 9.6), being positively charged at physiologic $\mathrm{pH}$. The strategies followed to control GFs release involve the encapsulation of PRHds into hydrogels of negatively charged polymers. ${ }^{50,68,81}$ In fact, it seems that is possible to modulate the release of specific PL-origin growth factors using materials with different sulfation degrees. ${ }^{110}$ For instance, low sulfated polysaccharides presented high affinity to PDGF, while heparin showed high affinity only for VEGF, resulting in phenotypic changes in ASCs seeded on surfaces coated with each polymer and PL. ${ }^{110}$
Finally, the TE strategies proposed so far for PRHds-based periodontal TE are very simplistic and only few of them propose dedicated approaches for each periodontal compartment. Future strategies should procure to produce compartmentalized approaches based on PRHds, employing specific materials, architectures and cells for each tissue. Three dimensionalprinting technologies have been evolving in terms of precision and versatility of printing. ${ }^{24111}$ Moreover, the use of mild bioprinting conditions would allow to print proteins, ${ }^{112}$ and cell-laden scaffolds. ${ }^{113}$ Thus, the future of periodontal TE could anticipate fully autologous and patient designed therapies for the predictable regeneration of periodontal defects.

In sum, future research on PRHds' application for periodontal TE should focus on the following aspects:

- Definition of GMPs or standard procedures in order to assure the reproducibility of the treatments;

- Investigate new materials to modulate the release of PRHdorigin growth factors;

- Explore bioprinting technologies and develop printable PRHdcarriers with defined architecture and chemical composition;

- Given the limited availability of some PRHds, study new storage strategies or the safeness of allogenic administration.

\section{Conclusions}

The ultimate goal of TE directed for periodontal tissue is the full regeneration of the lost tissues after trauma or periodontal disease to their original morphology and function. Nevertheless, the regeneration of periodontal tissue is a challenging task. Current scientific evidences suggest that a single approach is unlikely to succeed and the regeneration of periodontal tissue depends upon the provision of a stable surface for the ingrowth of both soft and hard tissues. In parallel, the invasion of periodontal wound with gingival soft tissue should be prevented. Of paramount importance is the delivery of adequate signaling molecules to promote the recruitment of suitable progenitor cells and differentiate them into functional tissues. Therefore, bi-layered compartmentalized systems provide the most promising design to meet the requirements of the various tissues involved while addressing the need for preventing the invasion of periodontal wound with gingival soft tissue.

The PRHds have arisen as an important source of GFs and structural proteins for TE. They offer the possibility of avoiding the use of xenogenic materials providing a "natural" release system for various GF involved in periodontal regeneration. The ability to be incorporated into several TE scaffolds, improving their biological performance enlarges the applicability of PRHds for periodontal therapies. Nevertheless, the plurality of processing protocols and the donor-to-donor variability still overshadow the needed reproducibility of PRHds medical application.

Future works should focus on the definition of the most adequate physicochemical design of scaffolds/materials aiming the delivery of PRHds targeting specific periodontal tissues, based, for instance, in sulfated polymers, known to modulate the release of specific PL growth factors. ${ }^{110}$ Additionally, attention 
should be paid to reproducibility of the PRHds' batches. Finally, the preparation of PRHds is time consuming and requires specific equipment which are not common in clinical practice, therefore attention should be given to strategies for preserving autologous PRHds and its storage. Alternatively, the definition of GMPs aiming safeness of allogenic PRHds administration should be attempted.

\section{Acknowledgements}

P. S. B. acknowledges FCT for the PhD grant SFRH/BD/73403/2010.

\section{References}

1 A. Nanci and D. D. Bosshardt, Periodontology 2000, 2006, 40, 11-28.

2 G. C. Armitage, Periodontology 2000, 2004, 34, 9-21.

3 M. Tobita and H. Mizuno, Curr. Stem Cell Res. Ther., 2010, 5, 168-174.

4 B. L. Pihlstrom, B. S. Michalowicz and N. W. Johnson, Lancet, 2005, 366, 1809-1820.

5 F. A. Scannapieco, Dent. Clin. North Am., 2005, 49, 533-550, vi. 6 P. I. Eke, B. A. Dye, L. Wei, G. D. Slade, G. O. ThorntonEvans, W. S. Borgnakke, G. W. Taylor, R. C. Page, J. D. Beck and R. J. Genco, J. Periodontol., 2015, 86, 611-622.

7 F. M. Chen and Y. Jin, Tissue Eng., Part B, 2010, 16, 219-255.

8 G. Polimeni, A. V. Xiropaidis and U. M. Wikesjo, Periodontology 2000, 2006, 41, 30-47.

9 J. D. Bashutski and H. L. Wang, J. Endod., 2009, 35, 321-328.

10 A. H. Melcher, C. A. McCulloch, T. Cheong, E. Nemeth and A. Shiga, J. Periodontal Res., 1987, 22, 246-247.

11 T. Karring, S. Nyman, J. Gottlow and L. Laurell, Periodontology 2000, 1993, 1, 26-35.

12 D. Buser, K. Warrer and T. Karring, J. Periodontol., 1990, 61, 597-601.

13 J. Gottlow, S. Nyman, T. Karring and J. Lindhe, J. Clin. Periodontol., 1984, 11, 494-503.

14 P. S. Babo, R. L. Pires, R. L. Reis and M. E. Gomes, Cienc. Tecnol. Mater., 2014, 26, 108-117.

15 J. H. Kim, C. H. Park, R. A. Perez, H. Y. Lee, J. H. Jang, H. H. Lee, I. B. Wall, S. Shi and H. W. Kim, J. Dent. Res., 2014, 93, 1203-1211.

16 S. Ivanovski, C. Vaquette, S. Gronthos, D. W. Hutmacher and P. M. Bartold, J. Dent. Res., 2014, 93, 1212-1221.

17 P. S. Babo, X. Cai, A. S. Plachokova, R. L. Reis, J. A. Jansen, M. E. Gomes and X. F. Walboomers, Tissue Eng., Part A, 2016, 22, 1164-1175.

18 J. F. Requicha, C. A. Viegas, F. Munoz, J. M. Azevedo, I. B. Leonor, R. L. Reis and M. E. Gomes, Tissue Eng., Part A, 2014, 20, 2483-2492.

19 J. F. Requicha, T. Moura, I. B. Leonor, T. Martins, F. Munoz, R. L. Reis, M. E. Gomes and C. A. Viegas, J. Orthop. Res., 2014, 32, 904-909.
20 T. Iwata, M. Yamato, H. Tsuchioka, R. Takagi, S. Mukobata, K. Washio, T. Okano and I. Ishikawa, Biomaterials, 2009, 30, 2716-2723.

21 P. Babo, V. E. Santo, A. C. Duarte, C. Correia, M. Costa, J. F. Mano, R. L. Reis and M. E. Gomes, Inflammation Regener., 2014, 34, 33-44.

22 C. H. Park, H. F. Rios, A. D. Taut, M. Padial-Molina, C. L. Flanagan, S. P. Pilipchuk, S. J. Hollister and W. V. Giannobile, Tissue Eng., Part C, 2014, 20, 533-542.

23 C. H. Park, H. F. Rios, Q. Jin, J. V. Sugai, M. Padial-Molina, A. D. Taut, C. L. Flanagan, S. J. Hollister and W. V. Giannobile, Biomaterials, 2012, 33, 137-145.

24 F. Obregon, C. Vaquette, S. Ivanovski, D. W. Hutmacher and L. E. Bertassoni, J. Dent. Res., 2015, 94, 143S-152S.

25 B. M. Seo, M. Miura, S. Gronthos, P. M. Bartold, S. Batouli, J. Brahim, M. Young, P. G. Robey, C. Y. Wang and S. Shi, Lancet, 2004, 364, 149-155.

26 S. Choi, T. J. Cho, S. K. Kwon, G. Lee and J. Cho, Int. J. Oral Sci., 2013, 5, 7-13.

27 B. Inanc, A. E. Elcin and Y. M. Elcin, Tissue Eng., 2006, 12, 257-266.

28 N. Yu, D. A. Oortgiesen, A. L. Bronckers, F. Yang, X. F. Walboomers and J. A. Jansen, J. Clin. Periodontol., 2013, 40, 698-706.

29 H. Kawaguchi, A. Hirachi, N. Hasegawa, T. Iwata, H. Hamaguchi, H. Shiba, T. Takata, Y. Kato and H. Kurihara, J. Periodontol., 2004, 75, 1281-1287.

30 B. Inanc, A. E. Elcin, E. Unsal, K. Balos, A. Parlar and Y. M. Elcin, Artif. Organs, 2008, 32, 100-109.

31 J. F. Requicha, C. A. Viegas, F. Munoz, J. M. Azevedo, I. B. Leonor, R. L. Reis and M. E. Gomes, Tissue Eng., Part A, 2014, 20, 2483-2492.

32 M. Tobita, A. C. Uysal, R. Ogawa, H. Hyakusoku and H. Mizuno, Tissue Eng., Part A, 2008, 14, 945-953.

33 K. Nakajima, T. Abe, M. Tanaka and Y. Hara, J. Periodontal Res., 2008, 43, 681-688.

34 C. Parrilla, W. Lattanzi, A. Rita Fetoni, F. Bussu, E. Pola and G. Paludetti, Head Neck, 2010, 32, 310-318.

35 J. F. Requicha, C. A. Viegas, F. Munoz, R. L. Reis and M. E. Gomes, Anat. Rec., 2014, 297, 6-15.

36 D. A. Oortgiesen, X. F. Walboomers, A. L. Bronckers, G. J. Meijer and J. A. Jansen, J. Tissue Eng. Regener. Med., 2014, 8, 202-209.

37 S. An, X. Huang, Y. Gao, J. Ling, Y. Huang and Y. Xiao, Int. J. Mol. Med., 2015, 36, 705-711.

38 C. Preeja and S. Arun, Saudi J. Dent. Res., 2014, 5, 117-122.

39 E. Anitua, M. Sanchez, A. T. Nurden, P. Nurden, G. Orive and I. Andia, Trends Biotechnol., 2006, 24, 227-234.

40 E. Anitua, R. Prado, S. Padilla and G. Orive, Platelets, 2015, 26, 281-282.

41 R. Crespo-Diaz, A. Behfar, G. W. Butler, D. J. Padley, M. G. Sarr, J. Bartunek, A. B. Dietz and A. Terzic, Cell Transplant., 2011, 20, 797-811.

42 N. Fekete, M. Gadelorge, D. Furst, C. Maurer, J. Dausend, S. Fleury-Cappellesso, V. Mailander, R. Lotfi, A. Ignatius, 
L. Sensebe, P. Bourin, H. Schrezenmeier and M. T. Rojewski, Cytotherapy, 2012, 14, 540-554.

43 E. Anitua, R. Prado, M. Azkargorta, E. Rodriguez-Suarez, I. Iloro, J. Casado-Vela, F. Elortza and G. Orive, J. Tissue Eng. Regener. Med., 2015, 9, E1-E12.

44 F. M. Chen, Y. An, R. Zhang and M. Zhang, J. Controlled Release, 2011, 149, 92-110.

45 R. E. Marx, J. Oral Maxillofac. Surg., 2004, 62, 489-496.

46 I. B. Copland, M. A. Garcia, E. K. Waller, J. D. Roback and J. Galipeau, Biomaterials, 2013, 34, 7840-7850.

47 M. B. Zucker, M. W. Mosesson, M. J. Broekman and K. L. Kaplan, Blood, 1979, 54, 8-12.

48 H. Li, T. Hamza, J. E. Tidwell, N. Clovis and B. Li, Adv. Healthcare Mater., 2013, 2, 1277-1284.

49 E. Anitua, R. Alonso, C. Girbau, J. J. Aguirre, F. Muruzabal and G. Orive, Clin. Exp. Dermatol., 2012, 37, 652-657.

50 P. S. Babo, R. L. Pires, L. Santos, A. Franco, F. Rodrigues, I. B. Leonor, R. L. Reis and M. E. Gomes, ACS Biomater. Sci. Eng., 2016, DOI: 10.1021/acsbiomaterials.6b00508.

51 M. R. Yeaman and A. S. Bayer, Drug Resist. Updates, 1999, 2, 116-126.

52 J. Krijgsveld, S. A. Zaat, J. Meeldijk, P. A. van Veelen, G. Fang, B. Poolman, E. Brandt, J. E. Ehlert, A. J. Kuijpers, G. H. Engbers, J. Feijen and J. Dankert, J. Biol. Chem., 2000, 275, 20374-20381.

53 F. W. Lam, K. V. Vijayan and R. E. Rumbaut, Compr. Physiol., 2015, 5, 1265-1280.

54 K. Krauel, C. Weber, S. Brandt, U. Zahringer, U. Mamat, A. Greinacher and S. Hammerschmidt, Blood, 2012, 120, 3345-3352.

55 H. Hamzeh-Cognasse, P. Damien, A. Chabert, B. Pozzetto, F. Cognasse and O. Garraud, Front. Immunol., 2015, 6, 82.

56 J. Choukroun, F. Adda, C. Schoeffer and A. Vervelle, Implantodontie, 2000, 42, 55-62.

57 R. E. Marx, Implant Dent., 2001, 10, 225-228.

58 I. Martineau, E. Lacoste and G. Gagnon, Biomaterials, 2004, 25, 4489-4502.

59 M. R. Messora, M. J. Nagata, R. C. Dornelles, S. R. Bomfim, F. A. Furlaneto, L. G. de Melo, T. M. Deliberador, A. F. Bosco, V. G. Garcia and S. E. Fucini, J. Periodontal Res., 2008, 43, 723-729.

60 G. Intini, S. Andreana, F. E. Intini, R. J. Buhite and L. A. Bobek, J. Transl. Med., 2007, 5, 13.

61 M. Matsui and Y. Tabata, Acta Biomater., 2012, 8, 1792-1801.

62 H.-L. Wang and G. Avila, Eur. J. Dent., 2007, 1, 192-194.

63 T. M. Fortunato, C. Beltrami, C. Emanueli, P. A. De Bank and G. Pula, Sci. Rep., 2016, 6, 25326.

64 D. M. Dohan Ehrenfest, I. Andia, M. A. Zumstein, C.-Q. Zhang, N. R. Pinto and T. Bielecki, Muscles, Ligaments Tendons J., 2014, 4, 3-9.

65 G. Weibrich, T. Hansen, W. Kleis, R. Buch and W. E. Hitzler, Bone, 2004, 34, 665-671.

66 P. Bajaj, A. R. Pradeep, E. Agarwal, N. S. Rao, S. B. Naik, N. Priyanka and N. Kalra, J. Periodontal Res., 2013, 48, 573-581.
67 G. Weibrich, W. K. Kleis, W. E. Hitzler and G. Hafner, Int. J. Oral Maxillofac. Implants, 2005, 20, 118-123.

68 I. Pallotta, J. A. Kluge, J. Moreau, R. Calabrese, D. L. Kaplan and A. Balduini, Biomaterials, 2014, 35, 3678-3687.

69 E. Anitua, R. Prado and G. Orive, Trends Biotechnol., 2013, 31, 364-374.

70 D. H. Whitman, R. L. Berry and D. M. Green, J. Oral Maxillofac. Surg., 1997, 55, 1294-1299.

71 L. A. Fortier, C. H. Hackett and B. J. Cole, Oper. Tech. Sports Med., 2011, 19, 154-159.

72 T. Yuan, C.-Q. Zhang and J. H. C. Wang, Muscles, Ligaments Tendons J., 2013, 3, 139-149.

73 N. Kakudo, T. Minakata, T. Mitsui, S. Kushida, F. Z. Notodihardjo and K. Kusumoto, Plast. Reconstr. Surg., 2008, 122, 1352-1360.

74 Q. Huang, Y. D. Wang, T. Wu, S. Jiang, Y. L. Hu and G. X. Pei, Chin. Med. J., 2009, 122, 83-87.

75 B. Goyal, S. Tewari, J. Duhan and P. K. Sehgal, J. Endod., 2011, 37, 773-780.

76 E. Anitua, M. Troya and G. Orive, J. Periodontol., 2013, 84, 1556-1566.

77 A. Albanese, M. E. Licata, B. Polizzi and G. Campisi, Immunity \& Ageing: I \& A, 2013, 10, 23.

78 M. Piemontese, S. D. Aspriello, C. Rubini, L. Ferrante and M. Procaccini, J. Periodontol., 2008, 79, 802-810.

79 J. Wiltfang, K. A. Schlegel, S. Schultze-Mosgau, E. Nkenke, R. Zimmermann and P. Kessler, Clin. Oral Implants Res., 2003, 14, 213-218.

80 A. Roffi, G. Filardo, E. Kon and M. Marcacci, BMC Musculoskeletal Disord., 2013, 14, 330.

81 G. Fernandes, C. Wang, X. Yuan, Z. Liu, R. Dziak and S. Yang, J. Periodontol., 2016, 87, 470-480.

82 J. Kurita, M. Miyamoto, Y. Ishii, J. Aoyama, G. Takagi, Z. Naito, Y. Tabata, M. Ochi and K. Shimizu, Ann. Thorac. Surg., 2011, 92, 837-844; discussion 844.

83 E. A. Anitua, J. Oral Implantol., 2006, 32, 72-76.

84 D. M. Dohan, J. Choukroun, A. Diss, S. L. Dohan, A. J. Dohan, J. Mouhyi and B. Gogly, Oral Surg., Oral Med., Oral Pathol., Oral Radiol., Endod., 2006, 101, e37-44.

85 H. Ajwani, S. Shetty, D. Gopalakrishnan, R. Kathariya, A. Kulloli, R. S. Dolas and A. R. Pradeep, J. Int. Oral Health, 2015, 7, 32-37.

86 A. R. Pradeep, N. S. Rao, E. Agarwal, P. Bajaj, M. Kumari and S. B. Naik, J. Periodontol., 2012, 83, 1499-1507.

87 S. Panda, S. Ramamoorthi, N. D. Jayakumar, M. Sankari and S. S. Varghese, J. Pharm. BioAllied Sci., 2014, 6, 127-131.

88 J. Choukroun, A. Diss, A. Simonpieri, M. O. Girard, C. Schoeffler, S. L. Dohan, A. J. Dohan, J. Mouhyi and D. M. Dohan, Oral Surg., Oral Med., Oral Pathol., Oral Radiol., Endod., 2006, 101, 299-303.

89 Z.-S. Wang, Z.-H. Feng, G.-F. Wu, S.-Z. Bai, Y. Dong, F.-M. Chen and Y.-M. Zhao, Sci. Rep., 2016, 6, 28126.

90 T. M. Fortunato, C. Beltrami, C. Emanueli, P. A. De Bank and G. Pula, Sci. Rep., 2016, 6, 25326.

91 T. Burnouf, D. Strunk, M. B. C. Koh and K. Schallmoser, Biomaterials, 2016, 76, 371-387. 
92 O. Trubiani, A. Piattelli, V. Gatta, M. Marchisio, F. Diomede, M. D'Aurora, I. Merciaro, L. Pierdomenico, N. M. Maraldi and N. Zini, Tissue Eng., Part C, 2015, 21, 52-64.

93 V. E. Santo, M. E. Gomes, J. F. Mano and R. L. Reis, J. Tissue Eng. Regener. Med., 2012, 6(suppl 3), s47-s59.

94 P. S. Babo, V. E. Santo, M. E. Gomes and R. L. Reis, Macromol. Biosci., 2016, 16, 1662-1677.

95 P. Babo, V. E. Santo, A. R. C. Duarte, C. Correia, M. H. G. Costa, J. F. Mano, R. L. Reis and M. E. Gomes, Inflammation Regener., 2014, 34, 033-044.

96 B. Goyal, S. Tewari, J. Duhan and P. K. Sehgal, J. Endod., 2011, 37, 773-780.

97 J.-H. Fu and H.-L. Wang, J. Evid. Based Dent. Pract., 2012, 12, 5-7.

98 A. S. Plachokova, J. van den Dolder, P. J. Stoelinga and J. A. Jansen, Clin. Oral Implants Res., 2007, 18, 244-251.

99 G. M. Raghoebar, J. Schortinghuis, R. S. Liem, J. L. Ruben, J. E. van der Wal and A. Vissink, Clin. Oral Implants Res., 2005, 16, 349-356.

100 D. M. Ranly, C. H. Lohmann, D. Andreacchio, B. D. Boyan and Z. Schwartz, J. Bone Jt. Surg., Am. Vol., 2007, 89, 139-147.

101 J. Magalon, O. Bausset, N. Serratrice, L. Giraudo, H. Aboudou, J. Veran, G. Magalon, F. Dignat-Georges and F. Sabatier, Arthroscopy, 2014, 30, 629-638.

102 A. Kalen, O. Wahlstrom, C. H. Linder and P. Magnusson, Biochem. Biophys. Res. Commun., 2008, 375, 261-264.

103 G. Weibrich, W. K. Kleis, G. Hafner and W. E. Hitzler, J. Craniomaxillofac. Surg., 2002, 30, 97-102.

104 P. R. Amable, R. B. Carias, M. V. Teixeira, I. da Cruz Pacheco, R. J. Correa do Amaral, J. M. Granjeiro and R. Borojevic, Stem Cell Res. Ther., 2013, 4, 67.

105 P. Hofbauer, S. Riedl, K. Witzeneder, F. Hildner, S. Wolbank, M. Groeger, C. Gabriel, H. Redl and W. Holnthoner, Cytotherapy, 2014, 16, 1238-1244.

106 R. X. Wu, Y. Yu, Y. Yin, X. Y. Zhang, L. N. Gao and F. M. Chen, J. Tissue Eng. Regener. Med., 2016, DOI: 10.1002/term.2124.
107 M. Yanagita, Y. Kojima, M. Kubota, K. Mori, M. Yamashita, S. Yamada, M. Kitamura and S. Murakami, J. Dent. Res., 2014, 93, 89-95.

108 T. Hidaka, T. Nagasawa, K. Shirai, T. Kado and Y. Furuichi, Arch. Oral Biol., 2012, 57, 830-840.

109 P. Arpornmaeklong, M. Kochel, R. Depprich, N. R. Kubler and K. K. Wurzler, Int. J. Oral Maxillofac. Surg., 2004, 33, 60-70.

110 S. M. Oliveira, V. E. Santo, M. E. Gomes, R. L. Reis and J. F. Mano, Biomaterials, 2015, 48, 56-65.

111 J. Yue, P. Zhao, J. Y. Gerasimov, M. van de Lagemaat, A. Grotenhuis, M. Rustema-Abbing, H. C. van der Mei, H. J. Busscher, A. Herrmann and Y. Ren, Adv. Funct. Mater., 2015, 25, 6756-6767.

112 M. J. Sawkins, P. Mistry, B. N. Brown, K. M. Shakesheff, L. J. Bonassar and J. Yang, Biofabrication, 2015, 7, 035004.

113 Z. Wu, X. Su, Y. Xu, B. Kong, W. Sun and S. Mi, Sci. Rep., 2016, 6, 24474.

114 J. B. Sipe, J. Zhang, C. Waits, B. Skikne, R. Garimella and H. C. Anderson, Bone, 2004, 35, 1316-1322.

115 S. Mehta and J. T. Watson, J. Orthop. Trauma, 2008, 22, 432-438.

116 E. Anitua, R. Tejero, M. M. Zalduendo and G. Orive, J. Periodontol., 2013, 84, 1180-1190.

117 N. Broggini, W. Hofstetter, E. Hunziker, D. D. Bosshardt, M. M. Bornstein, I. Seto, G. Weibrich and D. Buser, Clin. Implant Dent. Relat. Res., 2011, 13, 1-12.

118 W. Pluemsakunthai, S. Kuroda, H. Shimokawa and S. Kasugai, Inflammation Regener., 2013, 33, 164-172.

119 C. W. Hsu, K. Yuan and C. C. Tseng, Oral Surg., Oral Med., Oral Pathol., Oral Radiol., Endod., 2009, 107, 185-192.

120 A. Moroz, R. A. Bittencourt, R. P. Almeida, S. L. Felisbino and E. Deffune, Platelets, 2013, 24, 219-225.

121 P. Rastogi, H. Saini, R. Singhal and J. Dixit, J. Oral Biol. Craniofac. Res., 2011, 1, 41-43.

122 N. Bolukbasi, S. Yeniyol, M. S. Tekkesin and K. Altunatmaz, Curr. Ther. Res., Clin. Exp., 2013, 75, 15-21. 